\title{
Quality Mapping of Remote Elementary School-Based on e-EDS
}

\author{
Piter Joko Nugroho; Theo Jhoni Hartanto; Slamet Winaryo \\ Prodi Manejemen Pendidikan, Fakultas Keguruan dan Ilmu Pendidikan,Universitas Palangka Raya \\ J1. Yos Sudarso Kampus UPR Tunjung Nyaho, Palangka Raya, Indonesia \\ E-mail: piter@mp.upr.ac.id
}

Article received: July 2021; revised: july 2021 ; accepted : July 2021

DOI : $10.17977 /$ um025v5i32021p120

\begin{abstract}
This study aims to map the quality of elementary schools in remote areas in Kapuas and North Barito districts Central Kalimantan Province based on modified e-EDS by considering the ease of use and understanding of the "user" (principal of remote primary schools). This descriptive study using a qualitative approach was conducted in 9 (nine) remote elementary schools in the Kapuas and North Barito districts. Sources of data in this study consisted of nine school principals and the education officials from the two districts. Data collection techniques were carried out by interview (interview), observation, and e-EDS instruments which were developed referring to the SNP for elementary and secondary education. Data analysis using interactive data analysis. The data validation technique used the confirmability technique. The results showed that all elementary schools in remote areas received "red report cards". The issue of disparities in the quality of education in remote areas has not been properly handled by district and provincial policymakers and related stakeholders. In this article, we provide recommendations for conducting policy lending from countries that are successful in overcoming education problems in remote areas as a means of conducting policy lessons to address the quality problems of remote elementary schools in the future.
\end{abstract}

Keywords: mapping; elementary school quality; remote area; e-EDS

the quality of elementary and secondary education is the level of conformity between the implementation of elementary and secondary education with the National Education Standards (SNP) in the Elementary and Secondary Education units and/or expertise programs (Kemendikbud, 2016). SNP is a minimum standard set by the government in the field of education that must be met by education units and all stakeholders in managing and providing education, consisting of Graduate Competency Standards, Content Standards, Process Standards, Assessment Standards, Educators and Education Personnel Standards, Management Standards, Facilities, and Infrastructure Standards, and Financing Standards.

Every school should carry out quality assurance internally. This obligation is carried out to meet or exceed the established SPM and SNP. The main objective of quality assurance in schools is to improve learning processes and outcomes and build a culture of quality in schools (Chapman \& Sammons, 2013).

One of the tools that can be used to compile a school performance achievement profile on the SNP is through the School Self Evaluation (EDS). EDS is an internal school self-evaluation process that involves stakeholders to see school performance based on the SNP, the results of which are used as the basis for preparing the School Work Plan (RKS). EDS can be used by schools to collect data on school entities and data on the quality of education services concerning SNP. EDS is part of school quality mapping where this quality map provides initial data on the achievement of the 8 SNPs and their indicators that will facilitate stakeholders in preparing program planning and budgeting for quality improvement so that they have clear objectives, scope, targets, targets, and stages ( Satori, 2016).

Schools located in remote areas experience various obstacles and challenges related to the fulfillment/ achievement of 8 SNPs (Nugroho \& Hartanto, 2018). Not all schools (principals) know and understand 
the policies and procedures for carrying out school functions based on quality standards (Siddiqui, 2013). The results of observations made by researchers when carrying out a School Management Workshop at Remote Regional Elementary Schools in 2019 organized by the Astra Michael D. Ruslim Education Foundation (YPAMDR) in elementary schools around the mining site of a subsidiary of PT. Astra International in the Kapuas Regency and North Barito Regency, Central Kalimantan Province, also revealed the obstacles faced by remote schools regarding the fulfillment/achievement of the 8 SNPs, among others due to: (1) In general, remote elementary schools have never implemented EDS either manually, first or foremost. again application-based; so that practically the school quality development plan/program that is prepared is not based on the real quality gap experienced by the school, and (2) even if the principal knows the EDS application, they find it difficult to operate it and find it difficult to understand the meaning of the conclusions generated by the application.

Based on these conditions, it appears that EDS as "tools" that function to map the real condition of school quality based on the gap in fulfilling MSS and SNP is still not fully understood as a school need in preparing school planning and is seen as an important part in school development (Devos \& Verhoeven, 2003; Garira, 2020; Halsey, 2017). Maryadi (2019) stated that schools that implement EDS periodically will have the opportunity to advance schools because EDS is a strategic activity to find out the map of the quality of education in schools precisely and accurately. EDS is the basis for school reference in the preparation of RKS/RAKS as well as report material to the education office to be analyzed as input in the planning of various other educational quality improvement activities. The study also suggests improvements/improvements of the EDS instrument so that it can be more flexible, systematic, and practical, adapted to the ease with which users (schools) can use and understand it. This study aims to map the quality of elementary schools based on e-EDS which was developed by researchers by considering the practicality of users, in this case, the principals of remote elementary schools in the Kapuas Regency and North Barito Regency, Central Kalimantan Province.

\section{METHODS}

This research is a descriptive study that aims to explain or describe a situation, event, object, whether people or everything related to variables that can be explained both with numbers and words (Sugiyono, 2010). The paradigm used in this qualitative research is rationalistic postpositivism (Creswell, 2010). This paradigm views that science comes from individual understanding which is built on the ability to reason logically and is supported by relevant empirical data to describe the real map of the quality of education in elementary schools in remote areas. The data sources in this study consisted of 9 remote elementary school principals located in the Kapuas Regency Zone and North Barito Regency Zone, Central Kalimantan Province, as well as several personnel from the Kapuas Regency and North Barito Regency Education Offices. These elementary schools are located in the vicinity of the mining operations of several subsidiaries of PT. Astra International, namely: PT. Pama Persada Nusantara, PT. United Tractors, PT Asmin Bara Bronang, and PT. Kalimantan Prima Persada. The determination of the elementary schools was carried out after the researchers conducted interviews with the Education Offices of Kapuas Regency and North Barito Regency who suggested conducting research in the area on the basis of the consideration that schools in the area had never implemented EDS.

This research consists of three stages, the first stage: preliminary research studies, the second stage: designing the e-EDS application, and the third stage: collecting school quality mapping data using the e-EDS application. In the initial study stage, an analysis of the problems of the quality of education in schools was conducted through interviews and observations to the target elementary schools and the Education Offices of Kapuas Regency and North Barito Regency. Then identify the substance, especially for school self-evaluation (EDS). At the design stage, an e-EDS application is designed that will be used to collect school quality mapping data. In this stage, the research team modified the EDS application that had been developed by the LPMP of Central Kalimantan Province. This modification aims to make it easier for the user (in this case the target school) to use the e-EDS application. The modifications are related to (1) the display of the quality report card so that it is easily understood by the user (school), (2) the simplification of the language used in the application, and (3) the e-EDS filling guide. At the stage 
of data collection carried out in the target schools. Data analysis to reveal the profile of the education quality map in the target elementary school was carried out with the following steps: (1) analyzing the results of the research subject entries on the e-EDS which was intended to determine the achievement of quality standards in the target school, (2) confirming through interviews with the target school to check the correctness of certain data with data obtained from other sources (Sugiyono, 2011). The purpose of confirmation is to check the correctness of certain data with cross-checks, which is to compare the data obtained through e-EDS with school data in the field. Confirmation of this data is needed to ensure that the data provided/filled out by each school through e-EDS, truly describes the actual condition of the school. Based on the two steps above, it was then analyzed using interactive data analysis (Miles et al., 2014) with the following steps: (1) data condensation, (2) data presentation, and (3) concluding. The data validation technique used is Confirmability (certainty) by confirming the data to the data source, in this case, the principals of remote elementary schools who are the research subjects.

\section{RESULTS AND DISCUSSION}

\section{Quality Map of Elementary Schools in Remote Areas of Kapuas District}

The results of the e-EDS-based quality mapping conducted in remote elementary schools in the Kapuas District Zone are presented as follows:

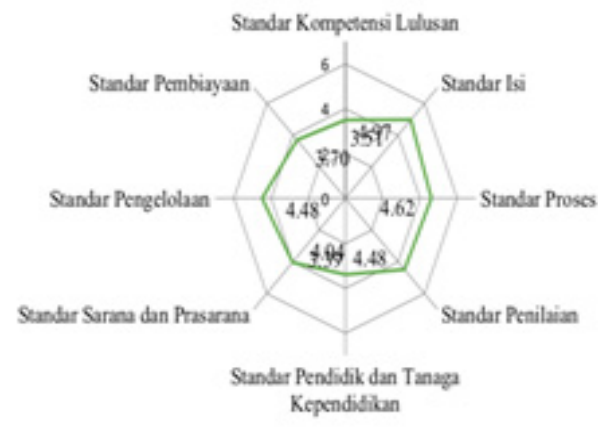

Figure 1. Chart of Quality of SDN 1 Barunang

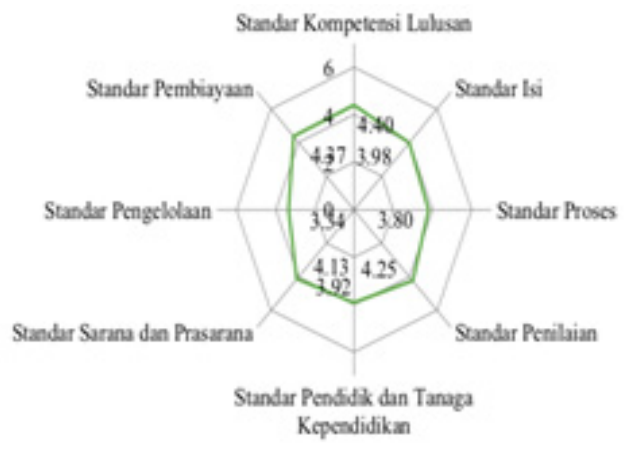

Figure 2. Chart of Quality of SDN Tbg. Mamput

Figure 1. shows that SDN 1 Barunang has gaps in the 7 components of the SNP, except Management Standards. Low-quality indicators in the 7 components of the SNP are items on (1) SKL, namely: graduates have competence in the knowledge dimension, and graduates have competence in the skills dimension, (2) Content Standards, namely: curriculum, (3) Process Standards, namely: planning the learning process, (4) Assessment Standards, namely: educational assessment benefits, and educational assessment instruments, (5) CAR standards, namely: educators, (6) Facilities and Infrastructure Standards, namely: land, buildings, and equipment facilities and infrastructure, (7) Financing Standards, namely: implementing cross-subsidies to help underprivileged students, and schools managing funds properly. The average SNP achievement at SDN 1 Barunang is 4.15. Based on the average score, it shows that SDN 1 Barunang is in the "Towards SNP Level 3" category. 
Figure 2. shows SDN 1 Tbg. Mamput experienced gaps in the 6 components of the SNP, except Process Standards and Financing Standards. Low-quality indicators in the 6 components of the SNP are items on (1) SKL, namely: graduates have competence in the knowledge dimension, and graduates have competence in the skills dimension, (2) Content Standards, namely: curriculum content, and curriculum, (3) Assessment Standards, namely: the benefits of education assessment, (5) CAR standards, namely: principal competence, fulfillment of the number of teachers, teacher qualifications, teacher competencies, and education personnel (TAS, librarians), (6) Facilities and Infrastructure Standards, namely: completeness of facilities and infrastructure, (7) Management Standards, namely: school guidelines, implementation of work plans, curriculum documents, principal leadership. On average, the SNP achievement at Tumbang Ablet Elementary School was at a score of 3.61. Based on the average score, it shows that Tumbang Ablet Elementary School is in the "Towards SNP Level 2" category.

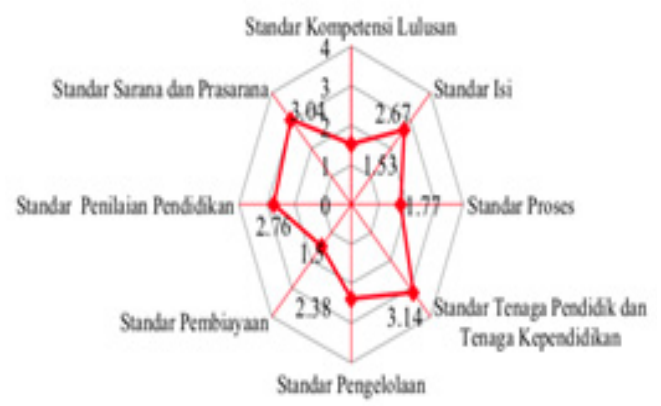

Figure 3. Chart of Quality of SDS Sakakarangan

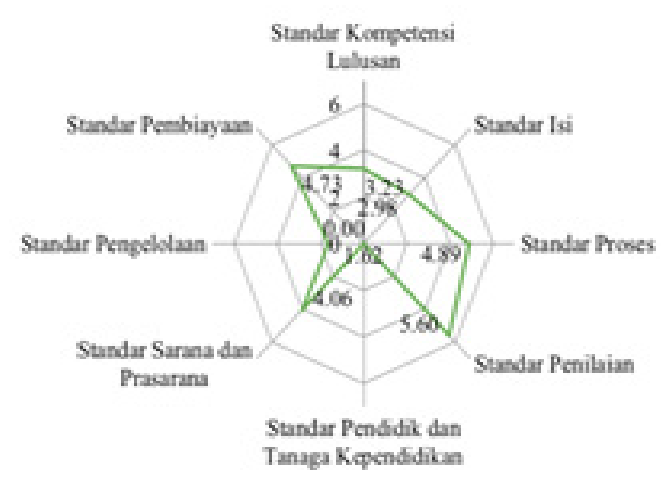

Figure 4. Chart of Quality of SDS Penda Rawah

Figure 3. shows that SDS Sakakarangan experiences gaps in all components of the SNP, including: (1) SKL, namely: related to knowledge, attitudes and knowledge competencies, (2) Content Standards, namely: curriculum tools (documents), (3) Process Standards, namely: implementation of scientific learning and model variations, methods in learning, (4) CAR standards, namely: school management (SBM) for school principals, supervision, monitoring and evaluation of schools, professional development of teachers through KKG, teacher qualifications, number of education personnel , (5) Management Standards, namely: school organizational structure, guidelines: students, curriculum, educators and education staff, school culture and environment, finance and financing, and PPDB activity mechanisms, (6) Assessment Standards, namely: assessment techniques used by teachers in learning, and assessment instruments, (7) Facilities and Infrastructure Standards, namely: fulfillment of minimum facilities and infrastructure, and fulfillment of learning facilities, and (8) Financing Standards, namely: use of funds, reporting on the use of funds, and supporting documents for reporting. On average, the SNP achievement at SDS Sakakarangan was at a score of 2.35. Based on the average score, it shows that SDS Sakakarangan is in the category "Towards SNP Level 2".

Figure 4. shows the SDS Penda Rawah experiencing gaps in the 6 components of the SNP, except Process Standards and Financing Standards. Low-quality indicators in the 6 components of the SNP are items on (1) SKL, namely: graduates have competence in the knowledge dimension, and graduates 
have competence in the skills dimension, (2) Content Standards, namely: curriculum content, and curriculum, (3) Assessment Standards, namely: the benefits of education assessment, (5) CAR standards, namely: principal competence, fulfillment of the number of teachers, teacher qualifications, teacher competencies, and education personnel (TAS, librarians), (6) Facilities and Infrastructure Standards, namely: completeness of facilities and infrastructure, (7) Management Standards, namely: school guidelines, implementation of work plans, curriculum documents, principal leadership. On average, the SNP achievement at SDS Penda Rawah was at a score of 3.40. Based on the average score, it shows that SDS Penda Rawah is in the category "Towards SNP Level 2".

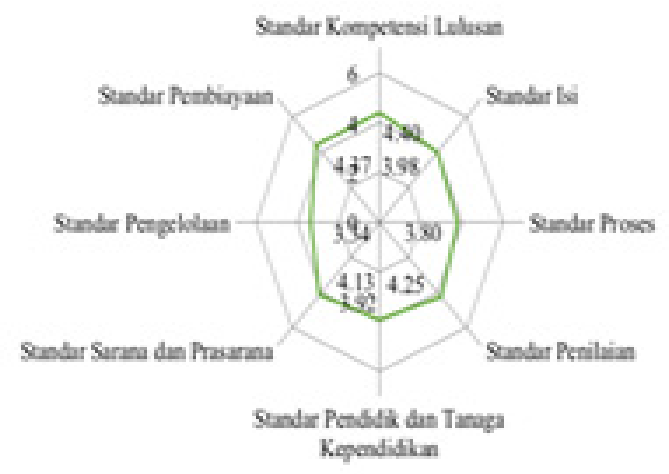

Figure 5. Chart of Quality of SDN 1 Buhut Jaya

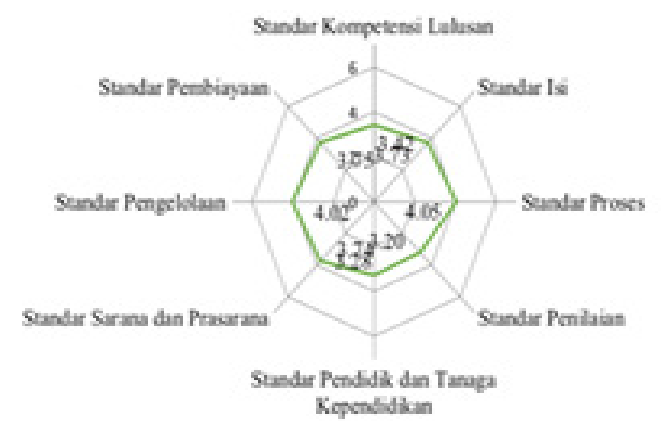

Figure 6. Chart of Quality of SDN 1 Buhut

Figure 5. shows SDN 1 Buhut Jaya experiencing gaps in all components of the SNP, including: (1) SKL, namely: graduates have competence in the attitude dimension, and graduates have competence in the knowledge dimension, (2) Content Standards, namely: curriculum content, and curriculum, (3) Process Standards, namely: implementation of learning and assessment implementation, and supervision of the learning process, (4) Assessment Standards, namely: scope of educational assessment, educational assessment objectives, and educational assessment instruments, (5) CAR Standards, namely : school administration staff, and library staff, (6) Facilities and Infrastructure Standards, namely: buildings, and completeness of facilities and infrastructure, (7) Management Standards, namely: implementation of work plans, monitoring and evaluation, information systems and management, and (8) Financing Standards, namely: school operational expenses according to the provisions, and schools managing funds properly. On average, the SNP achievement at SDN 1 Buhut Jaya is at a score of 4.02. Based on the average score, it shows that SDN Buhut Jaya is in the category "Towards SNP Level 3".

Figure 6. shows SDN 1 Buhut experiencing gaps in all SNP components, including: (1) SKL, namely: graduates have competence in the attitude dimension, graduates have competence in the knowledge dimension, and graduates have competence in the skills dimension, (2) Content Standards, namely: curriculum content, and curriculum, (3) Process Standards, namely: implementation of learning and implementation of assessments, and supervision of the learning process, (4) Assessment Standards, namely: scope of educational assessment, objectives of educational assessment, and educational assessment instruments, ( 5) CAR standards, namely: school administration staff, and library staff, (6) Facilities and Infrastructure Standards, namely: buildings, and completeness of facilities and 
infrastructure, (7) Management Standards, namely: implementation of work plans, supervision and evaluation, information and management systems, and (8) Financing Standards, namely: schools provide cross-subsidies, and school operational burdens according to regulations. The average SNP achievement at SDN 1 Buhut is 3.65. Based on the average score, it shows that SDN Buhut is in the category "Towards SNP Level 2".

\section{Quality Map of Elementary Schools in Remote Areas of North Barito Regency}

The results of the e-EDS-based quality mapping conducted in remote elementary schools in the District of North Barito Zone are presented as follows:

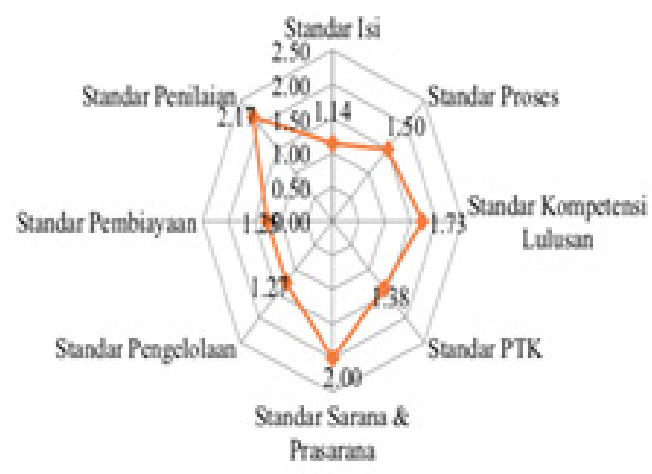

Figure 7. Chart of Quality of SDN 3 Lemo

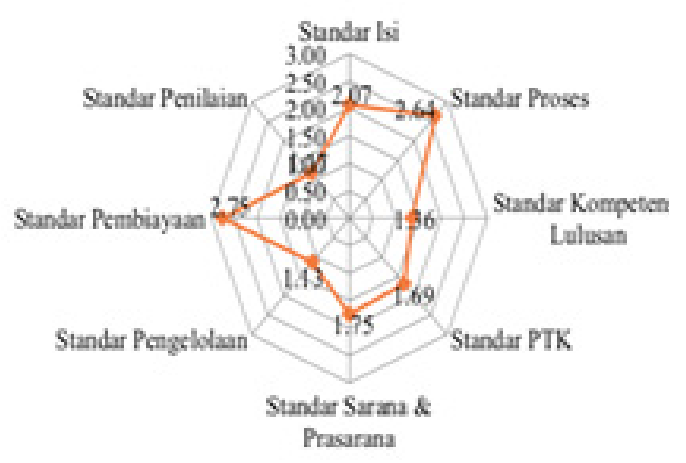

Figure 8. Chart of Quality of SDN 1 Paring Lahung

Figure 7. shows SDN 3 Lemo experiencing gaps in all SNP components, including (1) SKL, namely: graduates have competence in the attitude dimension, graduates have competence in the knowledge dimension, and graduates have competence in the skills dimension, (2) Content Standards, namely: curriculum content, design of subjects and learning loads, and curriculum, (3) Process Standards, namely: learning planning, implementation of learning and implementation of assessments, and supervision of the learning process, (4) Assessment Standards, namely: scope of educational assessment, educational assessment objectives, educational assessment mechanisms, educational assessment procedures, and educational assessment instruments, (5) CAR standards, namely: school administration staff, and library staff, (6) Facilities and Infrastructure Standards, namely: buildings, and completeness of facilities and infrastructure. infrastructure, (7) Management Standards, namely: implementation of work plans, monitoring and evaluation, information and management systems, and (8) S Funding standards, namely: schools provide cross-subsidies, and school operational burdens are under the provisions. On average, the SNP achievement at SDN 3 Lemo is at a score of 1.52. Based on the average score, it shows that SDN 3 Lemo is in the "Towards SNP Level 1" category.

Figure 8. shows SDN 1 Paring Lahung experiencing gaps in all SNP components, including: (1) SKL, namely: graduates have competence in the attitude dimension, graduates have competence in the knowledge dimension, and graduates have competence in the skills dimension, (2) Standards Contents, namely: curriculum content, and curriculum, (3) Process Standards, namely: learning 
planning, implementation of learning and implementation of assessments, and supervision of the learning process, (4) Assessment Standards, namely: scope of educational assessment, objectives of educational assessment, assessment mechanism education, educational assessment procedures, and educational assessment instruments, (5) CAR standards, namely: school administration staff, and library staff, (6) Facilities and Infrastructure Standards, namely: buildings, and completeness of facilities and infrastructure, (7) Standards Management, namely: implementation of work plans, monitoring and evaluation, information and management systems, and (8) Financing Standards, namely: provide crosssubsidies, and school operational burdens according to regulations. The average SNP achievement at SDN 1 Paring Lahung is 1.75. Based on the average score, it shows that SDN 1 Paring Lahung is in the "Towards SNP Level 1" category.

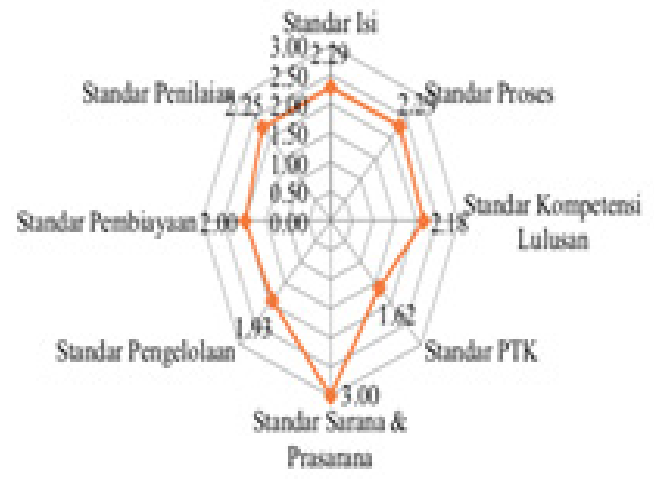

Figure 9. Chart of Quality of SDN 2 Paring Lahung

Figure 9. shows SDN 2 Paring Lahung experiencing gaps in all components of the SNP, including: (1) SKL, namely: graduates have competence in the attitude dimension, graduates have competence in the knowledge dimension, and graduates have competence in the skills dimension, (2) Standards Contents, namely: curriculum content, and curriculum, (3) Process Standards, namely: learning planning, implementation of learning and implementation of assessments, and supervision of the learning process, (4) Assessment Standards, namely: scope of educational assessment, objectives of educational assessment, assessment mechanism education, and educational assessment instruments, (5) CAR standards, namely: school administration staff, and library staff, (6) Facilities and Infrastructure Standards, namely: buildings, and completeness of facilities and infrastructure, (7) Management Standards, namely: implementation of work plans, monitoring and evaluation, information systems and management, and (8) Financing Standards, namely: schools providing cross-subsidies, and b. school operational expenses following the provisions. The average SNP achievement at SDN 2 Paring Lahung is 2.13. Based on the average score, it shows that SDN 2 Paring Lahung is in the "Towards SNP Level 1 " category.

\section{Recapitulation of Quality Map of Remote Area Elementary Schools Per Zone}

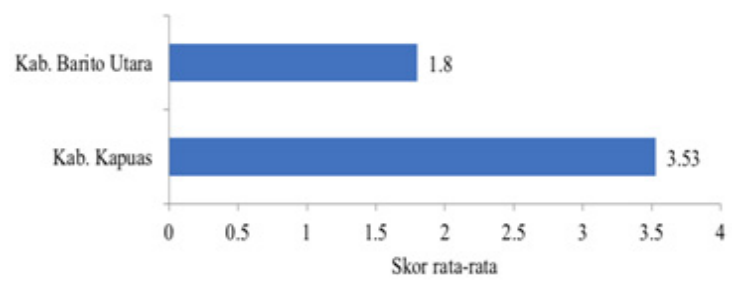

Figure 10. Average Quality Score of Remote Area Elementary Schools Per Zone

In general, the picture of the quality map of remote elementary schools in the Kapuas and North Barito Regencies is shown in Figure 10. The results of the recapitulation of the education quality map show that remote elementary schools located in the Kapuas Regency zone have an average score of 3.53. or "Towards SNP Level 2"; while remote elementary schools located in the North Barito Regency zone received an average score of 1.8 or "Towards SNP Level 1". The description of the quality map indicates that these remote elementary schools receive a "red report card" or are still experiencing a very large gap to the expected SNP. 
The results of the research which show the "red report card" of the quality of remote elementary schools in the Kapuas and North Barito districts based on the gap in the fulfillment of the SNP provide additional evidence that the problem of disparity in the quality of education in remote areas in Central Kalimantan since before the era of decentralization of education until the era of decentralization of education. Industrial revolution 4.0 has not been properly handled by policymakers from the provincial and district/city levels as well as related stakeholders. This finding further confirms that the policymakers in the districts of Kapuas and North Barito have not been serious enough to deal with the quality problems of elementary schools in remote areas in their regions. In general, this picture also applies to other remote elementary schools in Central Kalimantan were since the era before the reform until now there have not been many fundamental changes that show an improvement in the quality of basic education in remote areas in Central Kalimantan (Hasan, 2013; Nugroho, 2012, 2014). , 2017, 2018; Nugroho \& Hartanto, 2018; Siram, 1993, 2013).

The results of interviews with 9 remote elementary school principals who were the data sources in this study revealed various problems they faced while serving as principals who were far from the city center. So far they have complained about the lack of attention from the education office to facilitate various school needs, including school supervisors as an extension of the service which they expected to attend regularly to provide assistance to school principals and teachers, in fact, they make supervision visits every 6 months even 1 once a year; Even then, he only came briefly to check school documents and occasionally asked about the obstacles faced by the school which would then be forwarded to the education office. This kind of routine continues to be experienced by the principal while on duty. Complaints about school problems that are always submitted to the supervisor until now there has never been a clear follow-up action. Such conditions make school principals deadlocked, they are not able to carry out leadership to manage schools following applicable quality standards. Most of the principals also said that before and after serving as principals they rarely got enough knowledge and experience to be able to understand how to manage schools under applicable quality standards, especially with the various limitations they face in remote schools. Principals carry out leadership according to what they know and can do with the teachers, the important thing is that the education and learning process is carried out in schools and the children of the community can go to school. Whether the education and learning process carried out is following the applicable quality standards or not is another matter, because in reality they are almost never facilitated to be able to lead/manage schools properly according to applicable standards. Practical daily activities carried out by schools are carrying out routine school administrative work for reporting to the office. The results of the interview also reveal the principal's view of the office, which they believe knows what they need and what has been their problem so far. But in reality, until now the attention of the local government through the education office has not been on their side. The problems they have faced so far seem to not exist and everything is considered fine.

The quality gap that occurs in all components of the SNP in the findings of this study shows the powerlessness of school principals to make various changes in optimizing the implementation of education in the schools they lead. The target of low school quality is often addressed to school principals because school success and failure are determined by the ability, willingness, and hard work of the principal to strengthen all school staff (Beare et al., 2018; Gurr, 2015). As the highest leader in the school, the principal is obliged to mobilize every resource to commit to be actively involved together in building quality school achievements, especially the quality of learning (Goddard et al., 2015); but with various problems as conveyed by the principal, it is certain that this responsibility will not be easy (Hyson, 2013; Juharyanto, 2017).

A study conducted by Miller (2015) reveals that in practice, with various limitations, remote school principals are forced to filter policies and choose which they feel they can apply given the characteristics of their school. This is done because they do not have or do not know the policies and procedures to carry out school functions based on quality standards because they lack in the preparation period before becoming school principals as well as quality professional development during their careers, especially to lead schools that are unique/unique in remote conditions. Cortez-Jiminez, 2012; Dean, 2007; Elahi \& Ilyas, 2019; Salazar, 2007; Siddiqui, 2013), in addition to the lack of school facilities and resources, 
as well as the lack of support from policy authorities plus government policy factors that tend to change at any time, in practice, it makes it more difficult for school principals and overall has an impact on the very slow achievement of school quality (Juharyanto et al., 2019; Siddiqui, 2013).

Msila (2010) in her study explains that in reality, the education authorities tend not to care about the quality of education and even keep their distance instead of helping schools. In the Indonesian context, this also applies, for example in the appointment/appointment of school principals, especially in remote areas in general, they do not pay attention to the quality of their potential, only based on their willingness to be appointed as principal (Atsebeha, 2016; Juharyanto et al., 2020; Sigurðardóttir \& Sigpórsson, 2016), as well as potential teachers, in reality, have no desire to be promoted as principals, especially in remote schools (Juharyanto et al., 2020), arguing that these schools tend to be "difficult to managed" despite the additional compensation provided to principals and teachers for living in remote areas, it is often difficult to attract personnel to these locations (Clarke \& Wildy, 2011).

The various complexities of problems faced by remote schools (principals) should receive serious attention and become a priority agenda that must be immediately addressed by the education authorities. The principal is not the sole leader who is solely responsible for the quality of the school even though his existence has the most strategic position in determining the future of the school, he is not able to carry out such complex tasks alone without support and guidance from the education authorities in the area in this role. and responsibilities of the District (read: district education office) (Clarke \& Wildy, 2011; Matthijs \& Blyth, 2015). Barber et al (2010) emphasized that many principals cannot be successful in leading their schools without the best district leadership. Although in practice revitalizing education policies, especially in rural/remote areas, is not an easy job, it must be done (Marwan et al., 2012). There is no panacea for education policy (Chubb \& Moe, 1990), but if the design and practice of the resulting education system are not appropriate it will lead to educational injustice and school failure (Hanushek \& Woessmann, 2010).

Reflecting on good practices carried out in countries that have succeeded in addressing the quality problems of remote areas education shows the shifting role played by the District in school reform (Anderson, 2006; Chrispeels et al., 2008; Clarke, 2011; Leithwood et al., 2019; Togneri \& Anderson, 2003). Districts are considered to play an indirect but important role in improving student outcomes (Wilkinson et al., 2019). Districts are described as collaborative partners for principals (Bottoms \& Fry, 2009), support by sharing responsibilities (Derrington \& Campbell, 2015; Honig, 2012), being facilitators or network builders (Clarke \& Wildy, 2011; Daly \& Finnigan, 2010 ), provide resources to support school leaders and build strategic partnerships with various stakeholders (Chapman, 2019). It is clear that the role of District support for school principals is taken seriously especially for those who face challenges in leading the improvement of education in small rural/remote schools. District commitment is an important requirement to ensure that all schools build their capacity as effectively as possible rather than relying on more general arrangements that tend to pursue 'administrative routines as usual. In other words, the District is not just "annoying background noise", but has an important role in facilitating school reform (Clarke, 2011).

This successful shift in the role of the District in reforming schools in remote areas in various countries should be a reference for education policymakers in Indonesia and Central Kalimantan, especially the District Education Offices of Kapuas and North Barito in revitalizing policies and programs to address these problems. low-quality remote education. This is a necessity considering that children who study in remote areas have the right to get the best educational services to develop aspects of rationality, dignity, ethics, and aesthetics as future generations of future leaders and Indonesian travel agents (Sonhadji, 2008). 2012). The concept of national education that echoes the philosophy of "Education for All" is only natural if quality education can reach all levels of society in all corners of this country, including those in remote areas; especially in the era of education autonomy, improving the quality of education is the responsibility and authority of local governments through the provincial/district/city education offices (Hidayat, 2016). 
Anderson (2003) describes some strategic actions common in many successful districts as a 'district-wide sense of efficacy'. District-level leaders were able to demonstrate a strong belief in the capacity of schools to achieve high standards of learning for all students and high leadership. The role of the principal that is currently developing in many countries is to focus on being a learning leader for the school community, not just as a building manager (Bitsadze, 2019). The new practice leads to the problem of preparing school principals to be able to carry out their roles by providing effective support through changing the form of supervision to school principals. Direct support to principals for their professional development has evolved from a focus on supervision to coaching, mentoring, and partnerships (Browne-Ferrigno \& Allen, 2006; Clarke \& Wildy, 2011; Johnson \& Chrispeels, 2010; Leithwood, 2010), from evaluating principals School and operational issues are aimed at helping principals to grow as instructional leaders (Honig \& Rainey, 2019).

Wilkinson et al (2019)'s study on schools located in remote/rural areas shows how the reforms implemented by the District can take different forms depending on the local context of the school. Such an approach is particularly valuable when reforms are undertaken in a country with a diversity of school cultures, philosophies, communities, geographic locations, school sizes, and ethical and religious backgrounds. Leithwood (2010) states greater flexibility of the District's role and response to schools and a conceptualization of change at the District level that recognizes "complexity" and "nonlinearity" is necessary. Districts must encourage principals' instructional leadership practices, otherwise, change will not be viable and sustainable (Kemmis et al., 2013; Wilkinson \& Kemmis, 2015); So fostering instructional leadership (including in remote schools) must be a key role of the district education office (Wilkinson et al., 2019).

Preston \& Barnes (2017) state that the development of instructional leadership capacity by the District is an attempt to reconcile or balance school and district policies. School supervisors visit schools more frequently than in the past and now have meetings focused on learning issues with principals as well as being important supporters of principals in their growth as instructional leaders (Honig, 2012; Honig et al., 2010, 2017; Honig \& Rainey, 2014). In this effort, changes by the District were made by requiring supervisors to relinquish their traditional emphasis from evaluating principals' performance, monitoring schools, compliance with various mandates, and working with other head office units to resolve operational issues such as facility improvements. Supervisors dedicate time to helping their principals grow in their capacity to ensure excellent teaching and learning in schools. The role of supervisors shifted from organizational managers to instructional leaders, shifting from a primary focus on operations and compliance to dedicating their time to assisting principals (Honig \& Rainey, 2019; Leithwood, 2010). If supervisors focus on helping principals grow as instructional leaders, then principals will do so so that the quality of teaching will improve and in the end, each student will realize excellent results (Honig \& Rainey, 2019).

In practice, to realize instructional leadership requires support and training through continuous professional learning opportunities. It will be embedded in work if it is "provided" when principals lead their schools in real situations, not in off-school workshops (Browne-Ferrigno \& Muth, 2006; Fink \& Resnick, 2001; LaPointe et al., 2006; Peterson, 2002; Zepeda et al., 2014). The involvement of the District's role in the process of supporting and supervising school principals requires them to redesign traditional supervision methods that have been carried out so far by controlling principals, shifting to supporting and guiding them. This change was followed by the need to reshape the roles and responsibilities of supervisors in district offices (Bitsadze, 2019).

The good practices carried out by various successful countries, on the one hand, can be a valuable reference for education authorities in Central Kalimantan, especially the Kapuas and North Barito districts in revitalizing various policies that have not been optimal for remote elementary schools; but on the other hand, of course, it will raise questions that may become distortions in its implementation in the field: "Do supervisors have adequate capacity to do so, and how can the education office ensure that assigned supervisors can carry out their duties well with full commitment so that supervisors can be an effective "coach" for school principals? Do the current principals have adequate capacity to keep up with the changes made by the education office? How is the education office preparing to fulfill its new 
role in helping principals become instructional leaders?". Of course these questions will accompany the "good faith" that will be carried out by the education authorities in Kapuas and North Barito Regencies in carrying out the revitalization efforts.

The study conducted by Hariri et al (2016) in the Indonesian context in its historical development and reality shows the complexity of the implementation of instructional leadership which requires certain antecedents that cannot be handled easily. Capacity building for supervisors, for example, should be a strategic choice, followed by building partnerships between supervisors and principals. This job requires the trust, skills, and credibility of supervisors, and independent learning from the principal; The District needs to be careful in selecting and preparing supervisors so that they can contribute to a supportive and collegial relationship between supervisors and school principals (Thessin, 2019) so that coaching for supervisors so that they can carry out instructional leadership development for school principals must also be well thought out by the District (Zamjani, 2016).

Chapman (2019) indicated the need to rearrange the job descriptions of supervisors when selecting supervisors so that they could become levers of change for their target schools. Prospective supervisors assigned with coaching responsibilities to principals should be screened and selected according to their demonstrated capacity to lead their learning, and know-how to create conditions that support them in exercising that leadership (Thessin, 2019). In the process, it becomes important for local officials (Bupati and/or Head of Service) to consider how to screen prospective supervisors by taking into account their capacity to lead learning and continue to empower supervisors to develop and implement their lesson plans and continue to reflect on evidence of their progress, including not losing important in future consideration by the district government regarding the overall assignment of the principal itself (Honig \& Rainey, 2019).

LaPointe et al (2006) stated that based on experience in the professional development of highperforming school principals across districts, it will be effectively implemented if guided by comprehensive policies and programs ranging from recruitment, pre-appointment professional development, selection, appointment, post-appointment learning opportunities., and succession evaluation and planning (Schmidt-Davis \& Bottoms, 2011). Enforcement of this policy is one of the strongest levers available to districts to improve the leadership quality of principals over time (Leithwood et al., 2019). In the context of supporting the development of principals' leadership, there must be a willingness from the district to change directions, in this case, the leadership of principals in schools in Indonesia does not only emphasize school management (Sumintono et al., 2019) but must be directed at leadership and leadership. instructional development (Lee \& Hallinger, 2012). This effort will be realized if the design of professional coaching for supervisors and principals is presented on an ongoing basis as stated (Tulowitzki, 2019) it becomes a necessity to have a training structure and further development at the level of principals and school supervision, without reliable professional development facilities for all. concerned parties, both supervisory authorities, and principals risk being trapped in old professional identities that no longer correspond to their current mission or emerging national aspirations.

Observing the good practices from various successful countries, a common thread can be drawn as a constructive effort that can be considered by the local government of Kapuas and North Barito Regencies through their education offices in revitalizing the quality of education in remote schools, namely: (1) shifting the role of the service education through optimizing the role of supervisors/supervisors that focus on the growth of the principal's instructional leadership, so that to realize it a policy regarding recruitment and professional development of supervisors is needed to carry out their duties professionally, and (2) in the future it is necessary to rethink the preparation period before recruitment and Principal assignments include continuing professional development in remote school contexts that also require policy for that specific work.

The two alternatives will implicitly be related to the problem of financing (budget) as stated by the Education Offices of the Kapuas and North Barito Regencies where until now they do not have a budget allocation that is specifically intended for the professional development of supervisors and principals of remote elementary schools. Suprapti's study (2014) reveals budget constraints at the central and 
regional levels as the most dominant problem seen in the journey of regional autonomy in Indonesia to date. However, Culture (2016) is of the view that the budget problem is more caused by education budgeting which is still dominated by operational and routine expenditures. Only a small number of regions (districts/cities) have been able to allocate education funds outside of these routine expenditures (Toyamah \& Usman, 2004). The availability of the budget and the different education budget allocation systems in each region, lead to inequality, injustice, inefficient, and less effectiveness (Suwandi, 2012).

Apart from the inefficiency of budget management in the practice of managing education in the autonomy era, several studies offer alternative solutions that can be done to minimize financing problems in implementing various innovative programs through synergistic partnerships established by the education office with stakeholders outside of education, in this case, business entities/companies. through funding support for Corporate Social Responsibility (CSR) programs (Adianto, 2018; Chopra \& Marriya, 2013; Kapelus, 2002; Wandina et al., 2016). Chapman (2019) confirms that there is evidence of a larger and more sustainable impact on remote areas' educational attainment disparities that require collaboration to be expanded to include partners and services from outside of education. CSR synergy in education is one of the national joint movements that need to be carried out as an alternative solution in the midst of the stagnation of education development in Indonesia (Naraduhita \& Sawarjuwono, 2012; Wilda \& Sunoko, 2020). The key factor in the implementation of CSR is the expectations of stakeholders that investment decisions will not only generate financial benefits but must also consider social and environmental aspects so that people's welfare can be improved (Hidayati, 2011), including through education (Aini et al., 2018; Putra et al., 2018).

In the Indonesian context, funding support from other parties is contained in legislation, including Law Number 20 of 2003 concerning the National Education System, Government Regulation Number 48 of 2008 concerning Education Funding, and Regulation of the Minister of Education and Culture Number 44 of 2012 concerning Fees and Contribution of Education Costs to Basic Education Units, which opens up space to build partnerships with other parties outside of education who have a concern and role in the education sector. This is accompanied by laws related to the obligation to carry out social and community responsibilities by business entities/companies, such as Law Number 40 of 2007 concerning Limited Liability Companies, Government Regulation Number 47 of 2012 concerning Social and Environmental Responsibility of Limited Liability Companies, Government Regulations Number 23 of 2010 concerning Mineral and Coal Mining Business Activities, and Decree of the Minister of Energy and Mineral Resources (Komen ESDM) Number 1824 K/30/MEM/2018 concerning Guidelines for Implementation of Community Development and Empowerment. The tangible manifestation of the role of the World of Business and Industry (Dudi) in supporting education development in Indonesia, including various programs to improve the quality of education in remote schools, can be realized through a synergistic partnership program, either programmatically carried out by schools through the school committee program, or the Dudi partnership program. together with the education office as a realization of social and environmental responsibility as well as community development and empowerment (Nugroho \& Hartanto, 2019).

Chapman (2019) explains that effective multi-agency partnership work is essential in tackling educational inequality. In the case of remote elementary schools in the Kapuas and North Barito regencies which are located around the mining operational areas of several mining subsidiaries, PT. Astra International opens up opportunities for local governments through the education offices in the two districts to establish strategic partnerships in the preparation and establishment of programs to improve the quality of education in remote areas through CSR funding support that can be designed and agreed upon together. To realize the various improvement efforts as described earlier, the scope of the partnership can be further expanded, for example by involving universities as professionals to support the design of planning for supervisors and principals as well as ongoing professional preparation and development programs focused on remote school contexts.

In the end, the effort to make changes returned to the education authorities in Kapuas and North Barito Regencies, Central Kalimantan Province, and other regions in Indonesia. To achieve the goal of improving the quality of schools (including in remote areas), as a developing country Indonesia through 
its district education leaders needs to borrow policies, followed by policy learning as stated (Lingard, 2010), adjusting to the context of schools in Indonesia (Sumintono et al., 2019). Policy lending needs to be pursued by translating or adapting it locally in the context of schools in Indonesia (Steiner-Khamsi, 2016). Although the idea of policy lending is opposed by Harris \& Jones (in Sumintono et al., 2019) who argue that policy lending is not always successful, contextualized policy lessons can be learned. Therefore, taking into account the policies and good practices of various countries that have succeeded in overcoming the problems of remote areas education can be a lesson for Indonesia in reforming remote areas education management practices in the future.

\section{CONCLUSION}

The description of the quality of elementary schools in remote areas in the Kapuas and North Barito regencies with a "red report card" shows that the problem of education quality in remote elementary schools in Central Kalimantan Province has not been properly handled by the district and provincial governments of Central Kalimantan. . These findings also provide additional evidence that the problem of disparity in the quality of education in Indonesia in general since before the era of decentralization of education until the era of the industrial revolution 4.0 is still a big problem that demands the seriousness of the government of the Republic of Indonesia through the Ministry of Education, Culture, Research, and Technology together with all relevant stakeholders. to redesign policies that will give birth to various breakthroughs to solve education problems in remote areas. As a recommendation of good practice in various countries that have succeeded in overcoming the problems of remote area education, it may be a lesson for us in reforming remote area education management practices in the future, adapted to the Indonesian context.

\section{REFERENCES}

Adianto. 2018. Program Corporate Social Responsibility dalam Perspektif Indeks Kepuasan Publik di Riau. Sosio Konsepsia, 6(1), 90-109.

Aini, E. N., Isnaini, I., Sukamti, S., \& Amalia, L. N. (2018). Pengaruh Tingkat Pendidikan Terhadap Tingkat Kesejahteraan Masyarakat di Kelurahan Kesatrian Kota Malang. Technomedia Journal, 3(1), 58-72. doi: https://Doi.org/10.33050/Tmj.V3i1.333

Anderson, S. E. 2003. The School District Role in Educational Change: A Review of The Literature. International Centre for Educational Change, 34(2), 25-45.

Anderson, S. E. 2006. The School District's Role in Educational Change. International Journal of Educational Reform, 15(1), 13-37.

Atsebeha, A. T. 2016. Principals' Leadership Styles and Their Effects on Teachers' Performance in the Tigray Region of Ethiopia. Pretoria: University of South Africa.

Barber, M., Whelan, F., \& Clark, M. 2010. Capturing the Leadership Premium: How the World's Top School Systems Are Building Leadership Capacity For The Future. London: Mckinsey.

Beare, H., Caldwell, B. J., \& Millikan, R. H. 2018. Creating an Excellent School: Some New Management Techniques. London: Routledge.

Bitsadze, M. 2019. How Georgia May Learn from Changes in Principal Support and Supervision Internationally. Journal of Educational Administration, 57(5), 582-590. https://Doi.org/10.1108/Jea-09-2019-226

Bottoms, G., \& Fry, B. 2009. The District Leadership Challenge: Empowering Principals to Improve Teaching and Learning. Report Research. Wallace: Southern Regional Education Board.

Browne-Ferrigno, T., \& Allen, L. W. 2006. Preparing Principals for High-Need Rural Schools: A Central Office Perspective about Collaborative Efforts to Transform School Leadership. Journal of Research in Rural Education, 21(1), 1-16.

Browne-Ferrigno, T., \& Muth, R. 2006. Leadership Mentoring and Situated Learning: Catalysts for Principalship Readiness and Lifelong Mentoring. Mentoring \& Tutoring, 14(3), 275-295.

Chapman, C. 2019. From Hierarchies to Networks: Possibilities and Pitfalls for Educational Reform ff The Middle Tier. Journal of Educational Administration, 57(5), 554-570. Https://Doi.org/10.1108/Jea-12-2018-0222 
Chapman, C., \& Sammons, P. 2013. School Self-Evaluation for School Improvement: What Works and Why? Report-Evaluative. United Kindong: Eric.

Chopra, A., \& Marriya, S. 2013. Corporate Social Responsibility and Education in India. Issues and Ideas in Education, 1(1), 13-22.

Chrispeels, J. H., Burke, P. H., Johnson, P., \& Daly, A. J. 2008. Aligning Mental Models of District and School Leadership Teams for Reform Coherence. Education and Urban Society, 40(6), 730-750. https://Doi. org/10.1177/0013124508319582

Chubb, J. E., \& Moe, T. M. 1990. Politics, Markets, and America's Schools. Washington DC: Brookings Institution Press.

Clarke, S. 2011. Improving the Small Rural or Remote School: The Role of The District. 55(1), 24-36.

Clarke, S., \& Wildy, H. 2011. Improving the Small Rural or Remote School: The Role Of The District. Australian Journal of Education, 55(1), 24-36.

Cortez-Jiminez, G. 2012. Leadership Needs of California Rural School Administrators. Unpublished Doctoral Dissertation. CA: San Diego State University.

Creswell, J. W. 2010. Research Design Pendekatan Kualitatif, Kuantitatif, dan Mixed. Yogyakarta: Pustaka Pelajar.

Daly, A. J., \& Finnigan, K. S. 2010. A Bridge Between Worlds: Understanding Network Structure to Understand Change Strategy. Journal of Educational Change, 11(2), 111-138.

Dean, D. R. 2007. Thinking Globally: The National College of School Leadership: A Case Study in Distributed Leadership Development. Journal of Research on Leadership Education, 2(1), 1-62.

Derrington, M. L., \& Campbell, J. W. 2015. Implementing New Teacher Evaluation Systems: Principals' Concerns and Supervisor Support. Journal of Educational Change, 16(3), 305-326.

Devos, G., \& Verhoeven, J. C. 2003. School Self-Evaluation-Conditions and Caveats: The Case of Secondary Schools. Educational Management \& Administration, 31(4), 403-420.

Elahi, F., \& Ilyas, M. 2019. Quality Management Principles and School Quality: Testing Moderation of Professional Certification of School Principal in Private Schools of Pakistan. TQM Journal, 31(4), 578-599. https://Doi. org/10.1108/Tqm-11-2018-0173

Fink, E., \& Resnick, L. B. 2001. Developing Principals as Instructional Leaders. Phi Delta Kappan, 82(8), 598610.

Garira, E. 2020. Needs Assessment for The Development of Educational Interventions to Improve Quality of Education: A Case of Zimbabwean Primary Schools. Social Sciences \& Humanities Open, 2(1), 100020.

Goddard, R., Goddard, Y., Sook Kim, E., \& Miller, R. 2015. A Theoretical and Empirical Analysis of The Roles of Instructional Leadership, Teacher Collaboration, and Collective Efficacy Beliefs in Support of Student Learning. American Journal of Education, 121(4), 501-530.

Gurr, D. 2015. A Model of Successful School Leadership from The International Successful School Principalship Project. Societies, 5(1), 136-150.

Halsey, J. 2017. Independent Review into Regional, Rural, and Remote Education. Discussion Paper. Australia: Department of Education and Training.

Hanushek, E. A., \& Woessmann, L. 2010. Education and Economic Growth. Economics of Education, 60-67.

Hariri, H., Monypenny, R., \& Prideaux, M. 2016. Teacher-Perceived Principal Leadership Styles, DecisionMaking Styles, and Job Satisfaction: How Congruent are Data from Indonesia with The Anglophile and Western Literature? School Leadership \& Management, 36(1), 41-62.

Hasan, R. 2013. Penyelenggaraan Progran SD-SMP Satu Atap dalam Latar Budaya Rumah Betang Kalimantan Tengah. Jurnal Ilmu Pendidikan, 19(2).

Hidayat, N. 2016. Otonomi Daerah dan Desentralisasi Pendidikan (Studi pada Jenjang Pendidikan Menengah Dinas Pendidikan Kota Sawahlunto). Society, 4(1), 35-50.

Hidayati, N. D. 2011. Pattern of Corporate Social Responsibility Programs: A Case Study. Social Responsibility Journal, 7(1), 104-117. https://Doi.org/10.1108/17471111111114576

Honig, M. I. 2012. District Central Office Leadership as Teaching: How Central Office Administrators Support Principals' Development as Instructional Leaders. Educational Administration Quarterly, 48(4), 733-774.

Honig, M. I., \& Rainey, L. R. 2014. Central Office Leadership in Principal Professional Learning Communities: The Practice Beneath the Policy. Teachers College Record, 116(4), 1-48.

Honig, M. I., \& Rainey, L. R. 2019. Supporting Principal Supervisors: What Really Matters? Journal of Educational Administration, 57(5), 445-462. https://Doi.org/10.1108/Jea-05-2019-0089 
Honig, M. I., Copland, M. A., Rainey, L., Lorton, J. A., \& Newton, M. 2010. Central Office Transformation for District-Wide Teaching and Learning Improvement. Research Report. Washington DC: Center for The Study of Teaching and Policy.

Honig, M. I., Venkateswaran, N., \& Mcneil, P. 2017. Research Use as Learning: The Case of Fundamental Change in School District Central Offices. American Educational Research Journal, 54(5), 938-971.

Hyson, P. 2013. The Spirited Leader: The Potential of Spiritual Intelligence to Improve Leadership. The International Journal of Leadership in Public Services.

Johnson, P. E., \& Chrispeels, J. H. 2010. Linking the Central Office and Its Schools for Reform. Educational Administration Quarterly, 46(5), 738-775.

Juharyanto, J. 2017. Kepemimpinan Unggul Kepala Sekolah Dasar Daerah Terpencil (Studi Multisitus pada Sekolah Dasar Di Kabupaten Bondowoso). Sekolah Dasar: Kajian Teori Dan Praktik Pendidikan, 26(1), 89-100.

Juharyanto, J., Sultoni, S., Arifin, I., \& Nurabadi, A. 2019. Kepemimpinan Kepala Sekolah dalam Penguatan Peran Multi-Stakeholders Forum (Masalah dan Strategi Solutif Peningkatan Mutu SD-SMP Satu Atap di Daerah Terpencil). Sekolah Dasar: Kajian Teori dan Praktik Pendidikan, 28(1), 1-10. https://Doi.org/10.17977/ Um009v28i12019p001

Juharyanto, J., Sultoni, S., Arifin, I., Bafadal, I., Nurabadi, A., \& Hardika, H. 2020. “Gethok Tular” as The Leadership Strategy of School Principals to Strengthen Multi-Stakeholder Forum Role in Improving the Quality of OneRoof Schools in Remote Areas in Indonesia. Sage Open, 10(2). https://Doi.org/10.1177/2158244020924374

Kapelus, P. 2002. Mining, Corporate Social Responsibility and the" Community": The Case of Rio Tinto, Richards Bay Minerals and The Mbonambi. Journal of Business Ethics, 39(3), 275-296.

Kemendikbud. 2016. Pedoman Umum Sistem Penjaminan Mutu Pendidikan Dasar dan Menengah. Jakarta: Direktorat Jenderal Pendidikan Dasar dan Menengah.

Kemmis, S., Wilkinson, J., Edwards-Groves, C., Hardy, I., Grootenboer, P., \& Bristol, L. 2013. Changing Practices, Changing Education. Singapore: Springer Science \& Business Media.

Lapointe, M., Davis, S., \& Cohen, C. 2006. School Leadership Study: Developing Successful Principals. Palo Alto, Ca: Stanford University.

Lee, M., \& Hallinger, P. 2012. National Contexts Influencing Principals' Time Use and Allocation: Economic Development, Societal Culture, and Educational System. School Effectiveness and School Improvement, 23(4), 461-482.

Leithwood, K. 2010. Characteristics of School Districts that are Exceptionally Effective in Closing the Achievement Gap. Leadership and Policy in Schools, 9(3), 245-291.

Leithwood, K., Sun, J., \& Mccullough, C. 2019. How School Districts Influence Student Achievement. Journal of Educational Administration, 57(5), 519-539. https://Doi.org/10.1108/Jea-09-2018-0175

Lingard, B. 2010. Policy Borrowing, Policy Learning: Testing Times in Australian Schooling. Critical Studies in Education, 51(2), 129-147.

Marwan, A., Bambang, S., \& Nora, M. 2012. Revitalizing Rural Schools: A Challenge for Malaysia. Educational Issues, Research and Policies, 11, 171-188.

Maryadi, M. 2019. Pengembangan Model Evaluasi Diri untuk Peningkatan Mutu Pendidikan. Paudia: Jurnal Penelitian dalam Bidang Pendidikan Anak Usia Dini, 8(1).

Matthijs, M., \& Blyth, M. 2015. The Future of The Euro. USA: Oxford University Press.

Miles, M. B., Huberman, M. A., \& Saldana, J. 2014. Qualitative Data Analysis: A Methods Sourcebook and The Coding Manual for Qualitative Researchers. Thousand Oaks, CA: SAGE.

Miller, P. 2015. Leading Remotely: Exploring the Experiences of Principals in Rural and Remote School Communities in Jamaica. International Journal of Whole Schooling, 11(1), 35-53.

Msila, V. 2010. Rural School Principals' Quest for Effectiveness: Lessons from the Field. Journal of Education, 48(1), 169-189.

Naraduhita, D. C., \& Sawarjuwono, T. 2012. Corporate Social Responsibility: Upaya Memahami Alasan dibalik Pengungkapan CSR Bidang Pendidikan. Jurnal Akuntansi dan Auditing, 8(2), 95-108.

Nugroho, P. J. 2012. Pengembangan Profesionalisme Guru Sekolah Dasar Pada Daerah Terpencil Kabupaten Gunung Mas. Jurnal Manajemen Pendidikan, 23(6), 513-531.

Nugroho, P. J. 2014. Faktor-Faktor yang Mempengaruhi Profesionalisme Guru SD Daerah Terpencil Kabupaten Gunung Mas Provinsi Kalimantan Tengah. Jurnal Pendidikan Lentera Dinas Pendidikan Kabupaten Bondowoso, 1(1), 19-36. 
Nugroho, P. J. 2017. Pemetaan Kompetensi Guru Sekolah Dasar Daerah Terpencil Daratan Pedalaman Kabupaten Gunung Mas. Jurnal Pendidikan, 18(1), 44-55.

Nugroho, P. J. 2018. Analisis Kebutuhan Model Pelatihan Untuk Meningkatkan Kompetensi Guru Sekolah Dasar Daerah Terpencil. Jurnal Ilmu Pendidikan, 23(2), 152-163.

Nugroho, P. J., \& Hartanto, T. J. 2018. Collaborative Training Model (Ctm): An Alternative Solution to Overcome Remote Areas Elementary Teacher Gaps on ICT Competencies. International Conference on Education and Technology (ICET 2018), 139-145.

Peterson, K. 2002. The Professional Development of Principals: Innovations and Opportunities. Educational Administration Quarterly, 38(2), 213-232.

Preston, J. P., \& Barnes, K. E. R. 2017. Successful Leadership in Rural Schools: Cultivating Collaboration. Rural Educator, 38(1), 6-15.

Putra, P. D., Nasir, M., \& Rozaini, N. 2018. Peningkatan Kesejahteraan Masyarakat melalui Pendidikan, Pemberdayaan Ekonomi, Peningkatan Sarana dan Prasarana Serta Kesehatan di Kota Gunung Sitoli: Implementasi Corporate Social Responsibility (CSR) PT. Pertamina (Persero) Marketing Operating Region. Jurnal Pengabdian Kepada Masyarakat, 24(3), 776. https://Doi.org/10.24114/Jpkm.V24i3.11611

Salazar, P. S. 2007. The Professional Development Needs of Rural High School Principals. The Rural Educator, $28(3)$.

Satori, D. 2016. Pengawasan dan Penjaminan Mutu Pendidikan. Bandung: Alfabeta.

Schmidt-Davis, J., \& Bottoms, G. 2011. Who's Next? Let's Stop Gambling on School Performance and Plan for Principal Succession. Atlanta: Southern Regional Education Board.

Siddiqui, F. K. 2013. Problems of Educational Management in Private Sector Relating to Elementary Education in The Province of Sindh. Grassroots, 47(1), 139-148.

Sigurðardóttir, S. M., \& Sigpórsson, R. 2016. The Fusion of School Improvement and Leadership Capacity in an Elementary School. Educational Management Administration \& Leadership, 44(4), 599-616.

Siram, R. 1993. Pelaksanaan Model Guru Kunjung Suatu Alternatif Pemerataan Pendidikan Sekolah Dasar Daerah Terpencl di Kalimantan Tengah. Tesis tidak Dipublikasikan. Malang: IKIP Malang.

Siram, R. 2013. Pelaksanaan Model Guru Kunjung di Daerah Terpencil. Jurnal Ilmu Pendidikan, 19(2).

Sonhadji, A. 2012. Human, Technology, And Education: Toward New Civilization. Malang: UM Press.

Steiner-Khamsi, G. 2016. New Directions in Policy Borrowing Research. Asia Pacific Education Review, 17(3), 381-390.

Sugiyono. 2010. Metode Penelitian Pendidikan: Pendekatan Kuantitatif. Bandung: Alfabeta.

Sugiyono. 2011. Metodologi Penelitian Kuantitatif Kualitatif dan R\&D. Bandung: Alfabeta.

Sumintono, B., Hariri, H., Nugroho, P. J., Izzati, U. A., \& Sriyanto, J. 2019. The Role of Districts in Supporting School Leaders' Instructional Leadership: A View and Experience from a Developing Country. Journal of Educational Administration, 57(5), 591-600. https://Doi.org/10.1108/Jea-09-2019-227

Suprapti, S. 2014. Analisis Kritis Manajemen Madrasah di Era Otonomi Daerah. Religi: Jurnal Studi Islam, 5(1), 102-123.

Suwandi, S. 2012. Arah Kebijakan Pemanfaatan dan Penyaluran Dana Pendidikan pada Era Otonomi Daerah. Jurnal Pendidikan Teknologi dan Kejuruan, 21(2).

Thessin, R. A. 2019. Establishing Productive Principal/Principal Supervisor Partnerships for Instructional Leadership. Journal of Educational Administration, 57(5), 463-483. https://Doi.org/10.1108/Jea-09-20180184

Togneri, W., \& Anderson, S. E. 2003. Beyond Islands of Excellence: What Districts can do to Improve Instruction and Achievement in All Schools. Report Evaluative. Washington DC: A Project of The Learning First Alliance [and] A Leadership Brief.

Toyamah, N., \& Usman, S. 2004. Alokasi Anggaran Pendidikan di Era Otonomi Daerah: Implikasinya terhadap Pengelolaan Pelayanan Pendidikan Dasar. Jakarta: Lembaga Penelitian Smeru.

Tulowitzki, P. 2019. Supporting Instructional Leadership and School Improvement? Reflections on School Supervision from A German Perspective. Journal of Educational Administration, 57(5), 571-581. https:// Doi.org/10.1108/Jea-03-2019-0040

Wandina, R. H., Arisanty, D., \& Normlenai, E. 2016. Implementasi Program CSR (Corporate Social Responsibility) PT. Adaro Indonesia Bidang Pendidikan di Kecamatan Tanta Kabupaten Tabalong. JPG (Jurnal Pendidikan Geografi), 3(6). 
Wilda, Y. A., \& Sunoko, A. 2020. Implementasi Corporate Social Responsibility (CSR) dalam Meningkatkan Mutu Kualitas Pendidikan SMK NU Banat Kudus. Ibriez: Jurnal Kependidikan Dasar Islam Berbasis Sains, $5(2), 169-182$.

Wilkinson, J., \& Kemmis, S. 2015. Practice Theory: Viewing Leadership as Leading. Educational Philosophy and Theory, 47(4), 342-358.

Wilkinson, J., Edwards-Groves, C., Grootenboer, P., \& Kemmis, S. 2019. District Offices Fostering Educational Change Through Instructional Leadership Practices in Australian Catholic Secondary Schools. Journal of Educational Administration, 57(5), 501-518. Https://Doi.org/10.1108/Jea-09-2018-0179

Zamjani, I. 2016. Dancing with Legitimacy: Globalisation, Educational Decentralisation, and The State in Indonesia. Unpublished Dissertation. Canberra: Australian National University.

Zepeda, S. J., Parylo, O., \& Bengtson, E. 2014. Analyzing Principal Professional Development Practices through the Lens of Adult Learning Theory. Professional Development in Education, 40(2), 295-315. 